\title{
Environment, nutrition, and management practices for far-off, close-up, and fresh cows on Canadian dairy farms-A retrospective descriptive study
}

\author{
Rita Couto Serrenho, ${ }^{1 *}$ (๑) Christopher Church, ${ }^{2}$ Darren McGee, ${ }^{2}$ and Todd F. Duffield ${ }^{1} \odot$ \\ ${ }^{1}$ Population Medicine, University of Guelph, Guelph, ON, N1G 2W1, Canada \\ ${ }^{2}$ Elanco Animal Health, Greenfield, IN 46140
}

\begin{abstract}
The complex and interrelated management components of dairy farming are associated with health, production, and profitability of the herd, yet there is limited objective data on current management practices of the far-off, close-up, and fresh periods across Canadian dairy farms. We aimed to describe management practices of Canadian dairy farms by using a pre-existing risk assessment tool and outline potential management opportunities. Upon veterinarians' or producers' request, a transition management risk assessment (The Vital 90, Elanco) was performed by trained observers $(\mathrm{n}=10)$ during farm visits $(\mathrm{n}=78)$ between August 2014 and March 2018. Most farms were in Ontario (n $=64)$, whereas the remaining were in Alberta $(\mathrm{n}=5)$, British Columbia $(\mathrm{n}=4)$, Manitoba $(\mathrm{n}=1)$, Prince Edward Island $(\mathrm{n}=2)$, Newfoundland $(\mathrm{n}=1)$, and Saskatchewan $(\mathrm{n}=1)$. The study included 79 questions about nutrition, pen management, and cow comfort of the dry (approximate ranges: far-off, -60 to $-20 \mathrm{~d}$ in milk; close-up, -20 to $0 \mathrm{~d}$ in milk) and fresh $(0-30 \mathrm{~d}$ in milk) periods. The herds averaged 125 milking cows, and most had 2 defined dry groups (81\%). Freestall (FS; 54\%) and straw-bedded loose pack (BP; 81\%) were the most common housing systems observed in the far-off and close-up periods, respectively. Heifers and cows were housed together in 56, 80, and $59 \%$ of the far-off, close-up, and fresh pens, respectively. A large proportion of the far-off (FS: $>100 \%$ stocking density; BP: $<9.3 \mathrm{~m}^{2} /$ cow; $41 \%$ ), close-up, and fresh pens (FS: $>80 \%$ stocking density; BP: $<13.9 \mathrm{~m}^{2} / \mathrm{cow} ; 52$ and $49 \%$, respectively) were overstocked. Poor water access was observed across all periods $(65,58$, and $24 \%$ of the faroff, close-up, and fresh, respectively). Only a few farms had proper heat abatement systems in place (absence of properly functioning soakers or fans; $<10 \%$ in the
\end{abstract}

Received June 25, 2021.

Accepted October 2, 2021.

*Corresponding author: rcoutose@uoguelph.ca dry and $15 \%$ in the fresh periods). Cows were able to sort their ration in $60 \%$ of the dry period pens and $31 \%$ of the fresh pens. In $73 \%$ of the farms, fresh cow health monitoring protocols were not in place. Colostrum cows and sick cows were housed together in $40 \%$ of the farms; $59 \%$ separated the newborn from the dam within 2 to $12 \mathrm{~h}$ of birth with colostrum harvested immediately thereafter. This work describes prevalent management practices in the dry and fresh periods and highlights areas for potential improvement. Future research should focus on the associations between management choices and health performance of dairy farms.

Key words: dairy cow, practices, assessment, transition

\section{INTRODUCTION}

A successful lactation relies on excellent transition period management (Jones and Kammel, 2014). Transition period is commonly defined as 3 wk prepartum and postpartum (Grummer, 1995), but it is recognized that the whole dry period influences health and performance of the upcoming lactation (Dann et al., 2006; Abuelo et al., 2021). Assessment of the transition period management can often be challenging given the interrelationships between risk factors and their complexity (Overton and Waldron, 2004; Nydam et al., 2017; Mills et al., 2020). The main goals of transition period management are to maximize nutrient intake and energy availability, control mineral balances, and optimize immunity (Nydam et al., 2017). Dairy producers, farm staff, and agriculture professionals assess different nutritional approaches, grouping strategies, housing facilities, and labor availability to maximize animals' health and welfare and farm efficiency (Jones and Kammel, 2014), which creates unique transition management strategies between farms.

Mills et al. (2020) investigated the perceived barriers for transition period improvement on Canadian dairy farms. In this qualitative study, nutrition and pen management, veterinary involvement, and producer's attitude toward change were defined as the main barriers for transition improvement (Mills et al., 2020). The 
best management practices, defined by research and organizational guidelines, are not always the practices observed on-farm, and many reasons could explain the existing gap between research data and on-farm reality. The improvement of transition management and motivation for change are driven by benchmarking (Sumner et al., 2018) and the ability to detect bottlenecks, which are not possible without good record keeping and continuous analysis of herd health and performance ( $\mathrm{Ny}-$ dam et al., 2017).

Management and welfare guidelines and best practices for disease prevention are available [e.g., ProAction (Dairy Farmers of Canada, 2021), Code of Practice (National Farm Animal Care Council, 2009)]. However, research data are constantly evolving, and some of the recommendations are not updated regularly. This, along with the lack of information regarding current practices of Canadian dairy farms justifies the importance of describing current the management practices.

By highlighting management opportunities, researchers and dairy consultants will be able to help producers improve transition management practices and herd performance. Standardized management definitions as well as consistent and uniform assessment across herds, will reduce the gap between research data and on-farm practices and help identify the common management flaws during the transition period. Our objectives were to assess current management practices in Canadian dairy farms and provide insight of on-farm management opportunities to improve animal health, and performance of dairy farms.

\section{MATERIALS AND METHODS}

This work is reported using the Strengthening the Reporting of Observational Studies in Epidemiology-Veterinary Extension (STROBE-Vet) guidelines (O'Connor et al., 2016).

\section{Farms and Inclusion Criteria}

Canadian dairy herds $(\mathrm{n}=78 ; 74$ Holstein and 4 Jersey farms) were selected based on a convenience sampling method. Farms were included in the study based on pre-existing data and producer's consent to share the data. Most farms were located in Ontario (n $=64)$, whereas the remaining were in Alberta $(\mathrm{n}=5)$, British Columbia $(\mathrm{n}=4)$, Manitoba $(\mathrm{n}=1)$, Prince Edward Island $(\mathrm{n}=2)$, Newfoundland $(\mathrm{n}=1)$, and Saskatchewan $(n=1)$. Upon veterinarian's, feed advisor's or producer's request, a transition management risk assessment was performed by trained observers ( $\mathrm{n}$ $=10$ ). The majority of the observers were veterinarians $(\mathrm{n}=9)$, and each received training from Elanco on proper use of the risk assessment tool qquestionnaire; The Vital 90 Days Analyzer - Dairy Risk Assessment (Vital 90 dRisk), Elanco, Greenfield, IN]. Farm visits (one per farm) to fulfill the questionnaire (risk assessment tool) occurred between August 2014 and March 2018.

\section{Risk Assessment Tool}

The risk assessment tool, the Vital 90 dRisk was developed by a group of dairy experts and aims to evaluate transition management (from $60 \mathrm{~d}$ before until $30 \mathrm{~d}$ after parturition). The tool is available as a mobile application (Elanco, 2013) for iPad on AppStore (Apple Inc.). It was created to provide an objective management evaluation. It had as a main goal helping consultants and producers minimize the animal health risk during the transition period. The development of the tool was based on published management research and nutritional recommendations and, in cases of insufficient or unavailable data, on expert opinion risk analysis (Cooke, 1991). The tool includes questions about comfort, nutrition, and pen management of the dry (far-off, approximately -60 to -20 DIM; close-up, approximately -20 to 0 DIM), and fresh (approximately 0-30 DIM) periods. Observers filled each survey in real-time while assessing each particular period on-farm. Each period is divided into 3 management areas: feeding management, pen management, and cow comfort. At the completion of each transition management assessment, the Vital 90 dRisk presents the top 8 bottlenecks, scored by an internal weighting system. The observer asked the producer, veterinarian, and feed advisor to discuss the respective 8 topics, and select the top 3 that they would prioritize. The final report would include only the selected 3 topics. The scored weighted system and selection of bottlenecks by farm were not a matter of study in this work.

\section{Data Processing and Analysis}

The original data set included the following variables: farm name, farm number, observer, date of the farm visit, number of milking cows (continuous), number of dry cows (continuous), number of dry groups (one vs. 2), and far-off, close-up, and fresh period specific questions presented in Tables 1, 2, 3, and 4. The risk assessment tool does not have a classification for a tiestall category for housing facility. In this case, tiestall facilities were entered as freestall (FS). From DHI data available for 71 farms at the time of the farm visit, $32 \%(\mathrm{n}=23)$ milked their cows in tiestall facilities (pipeline), $54 \%(\mathrm{n}=38)$ in a milking parlor, and $14 \%$ $(\mathrm{n}=10)$ in an automatic milking system. 
The risk assessment tool is structured so that for each variable, there is both a question number $(\mathbf{Q} \#)$ and the written question itself. For the majority of questions, the written answer options represent a designated risk level for the transition period $(\mathrm{A}, \mathrm{B}$, or $\mathrm{C}$ for the majority of the questions, with $\mathrm{A}=$ optimal, $\mathrm{B}$ = suboptimal, and $\mathrm{C}=$ poor, based on expert opinion; Cooke, 1991).

The data extracted from the risk assessment tool is organized by period (far-off, close-up, and maternity, and fresh period) and housing system within each period. Depending on these responses, the software follows different programming paths - a $\mathrm{Q} \#$ is a unique entry, but the same question might have a different Q\# depending on the housing system. For example, Q5, Q6, and Q13 represent the same written question "far-off: characterize heat stress abatement" with the same answer options for cows in FS, dry lot, and strawbedded loose-pack (BP) pen, respectively. Thus, when the only difference between repeated questions was the housing type, questions were merged. Merging was not possible when the question was the same, but the answer options differed; in this case, the original questions were kept. Questions with less than 3 entries (and not possible to merge) or with the same entry for all farms were removed. We included 79 questions about comfort, nutrition, and pen management of the dry (far-off and close-up) and fresh periods. All the data cleaning steps are presented in Supplemental Figure S1 (https://doi .org/10.17632/krn357zs6r.1; Couto Serrenho, 2021).

Cow comfort data from farms with only one dry cow group, when possible, were repeated in the far-off and close-up questions. Thus, questions relative to far-off and close-up represent the period relative to calving that cows were exposed to. When questions relative to the close-up pen did not apply to farms with one dry group (e.g., pen movements), those entries were only presented in the far-off questions.
To assess the overall stocking density in the far-off and close-up groups, 2 new variables were created. Because stocking density questions had different answers according to housing system, we merged answers based on their classification of management (A, B, or C).

Body condition score of the cows within pen was assessed by the observers (1-5 scale, measured in 0.25-point increments; Ferguson et al., 1994). Ration sortability was assessed visually based on the length of straw and hay particles present. The comfort of cows housed in FS pens were assessed using the size of the stall and the bedding surface offered.

Data cleaning (described above; e.g., deletion of original variables without information), processing (e.g., merging the same question from different programming paths), and analysis (descriptive statistics) were performed using SAS (SAS Institute Inc.) to analyze the prevalence of each response. Descriptive statistics were obtained using the FREQ and MEANS procedures.

\section{RESULTS}

The data set included 78 Canadian dairy herds. The herds averaged $125 \pm 100$ SD milking cows and most had 2 defined dry cow groups (81\%). In $90 \%$ of the farms, first lactation cows were $\geq 85 \%$ of mature weight. Freestall $(54 \%)$ and BP (81\%) pens were the most common housing systems observed in the far-off and close-up periods, respectively (Table 1). Heifers and cows were housed together in 56, 80, and 59\% of the far-off, close-up, and fresh pens, respectively (Table 1). This section is organized in order by period of the transition (far-off, close-up, and fresh periods, respectively) and area of management (feeding, pen management, and cow comfort). All questions, respective answer options (optimal, suboptimal, and poor), and results (prevalence) of each section are presented in Tables $2-10$.

Table 1. Proportions of housing system and parity grouping during dry (far-off and close-up) and fresh periods of 78 Canadian dairy farms included in a transition cow management descriptive study

\begin{tabular}{lccc}
\hline Item & Far-off $^{1}$ & Close-up $^{1}$ & Fresh and maternity $^{1}$ \\
\hline Housing system, \% (n) & & & \\
$\quad$ Straw-bedded loose pack & $41.0(32)$ & $80.8(63)$ & $53.9(42)$ \\
Freestall $^{2}$ & $53.9(42)$ & $18.0(14)$ & - \\
Dry lot or pasture & $5.1(4)^{3}$ & $1.3($ dry lot $=1)$ & 59.0 \\
Cows and heifers grouping, $\%$ & 55.8 & 79.5 & 41.0 \\
$\quad$ Together & 44.2 & 20.5 & \\
Separately & &
\end{tabular}

${ }^{1}$ Days relative to calving: far-off $=$ from dry-off ( $\sim 60 \mathrm{~d}$ before parturition) until $22 \mathrm{~d}$ before parturition; closeup = from $21 \mathrm{~d}$ before until parturition; fresh and maternity: first $30 \mathrm{~d}$ after parturition.

${ }^{2}$ Due to nonexistent tiestall option, farms with this type of housing facilities were entered as freestall. From DHI data available for 71 farms at the time of the farm visit, $32 \%(\mathrm{n}=23)$ milked their cows in tiestall facilities.

${ }^{3}$ Dry lot, $\mathrm{n}=3$; pasture, $\mathrm{n}=1$. 
Couto Serrenho et al.: DAIRY INDUSTRY TODAY

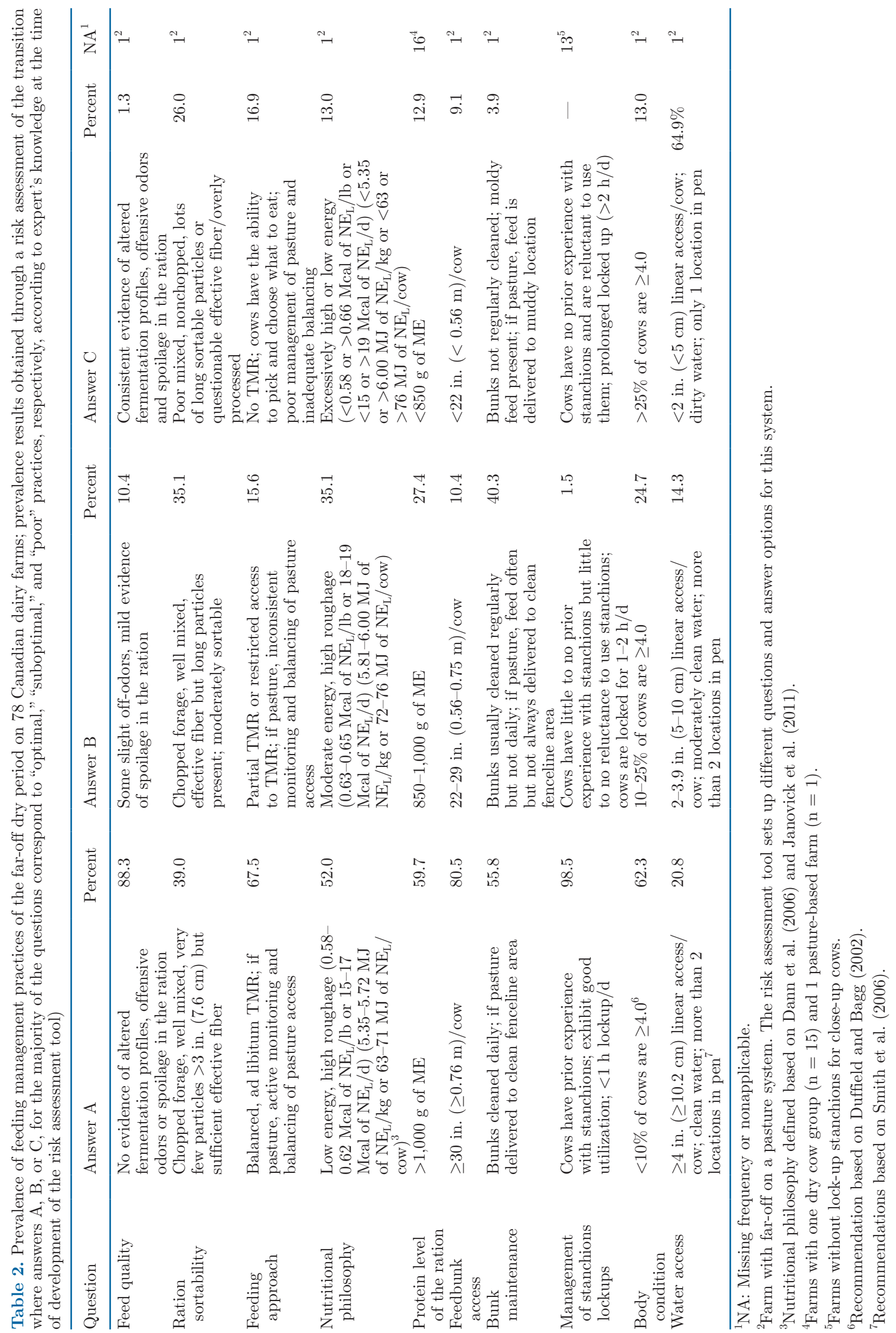




\section{Far-off Period}

Feeding Management. Most farms (68\%) provided a balanced ad libitum TMR, but a restricted TMR access (non-ad libitum) or absence of a TMR (hay and corn silage fed separately) was observed in approximately one-third of the farms (Table 2). More than half of the farms $(60 \%)$ could improve far-off ration sortability (Table 2) by controlling particle length, amount of effective fiber, and mixture of the ration. Moderate or excessively high or low energy were offered in $35 \%$ and $13 \%$, respectively, of the far-off groups; and $>50 \%$ of the far-off cows had access to low energy (5.35-5.72 MJ of $\mathrm{NE}_{\mathrm{L}} / \mathrm{kg}$ ), high roughage diet (Table 2). Far-off dry cows were offered $>1,000 \mathrm{~g}$ of $\mathrm{MP} / \mathrm{d}$ in $60 \%$ of the farms. An excessive proportion $(>10 \%)$ of overconditioned cows $(\mathrm{BCS} \geq 4)$ were presented in $38 \%$ of the farms. Most of the far-off ( $81 \%)$ cow groups had $\geq 0.76$ $\mathrm{m} /$ cow (optimal option) of feedbunk access, and bunks were cleaned daily in $56 \%$ of those (Table 2 ). Less than one-fourth of the far-off cow groups, had proper water access (optimal option; defined as $\geq 10.2 \mathrm{~cm} /$ cow linear access with clean water and with waterers in at least 2 locations within the pen (Table 2).

Pen Management. In the majority of the far-off (95\%) groups, cows were observed at least once daily (Table 3). In approximately half of far-off groups (51\%), more than one-fourth of the cows had dry periods outside of the recommended range $(40-70 \mathrm{~d})$; in $44 \%$ of the far-off groups, cows were moved once per week in groups of $\geq 10$ cows (Table 3 ).

Housing and Cow Comfort. In far-off cows housed in FS pens (53.8\%), there was opportunity for bedding and comfort improvement in approximately half of the farms (52\%); lunge access was obstructed in 36\% of the FS pens, and the stall dimensions were not ideal (optimal dimensions: $1.27-1.32 \mathrm{~m}$ wide and $\geq 1.77 \mathrm{~m}$ long) in $74 \%$ of these farms (Table 4). Overall, stocking density of the far-off period, considering both FS and BP pens, could be improved in $41 \%$ of the farms (Table 4). Lack of a proper and functioning heat abatement system was observed in $91 \%$ of far-off groups (Table 4). Dead-ends (side of the alley with no exit; one or more) were observed in $27 \%$ of the far-off pens (Table 4 ).

\section{Close-up Period}

Feeding Management. In the close-up groups, a partial or restricted access to TMR was observed in 19\% of the farms and the absence of a TMR was observed in $15 \% ; 60 \%$ of the farms could improve close-up ration sortability (Table 5). "Excessively high or low energy" $\left(>6.1\right.$ or $<5.5 \mathrm{MJ}$ of $\mathrm{NE}_{\mathrm{L}} / \mathrm{kg}$ ) was offered in $16 \%$ of the farms; $38 \%$ of the close-up cows were offered low 
Couto Serrenho et al.: DAIRY INDUSTRY TODAY

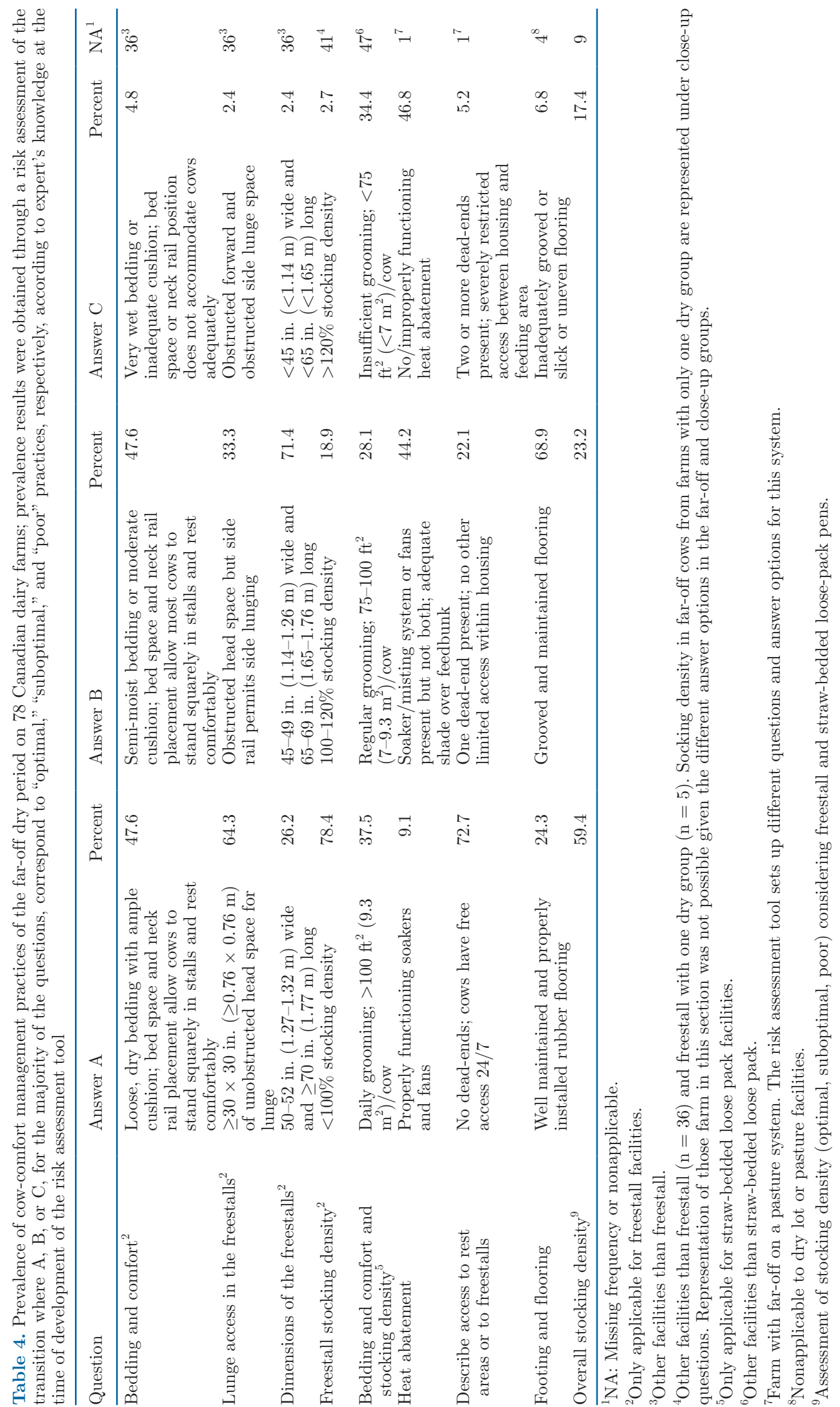


energy (5.5-5.8 $\mathrm{MJ}$ of $\mathrm{NE}_{\mathrm{L}} / \mathrm{kg}$ ) - high roughage diet (Table 5). In close-up, $50 \%$ of the groups were offered $<1,200 \mathrm{~g}$ of MP. An excessive proportion $(>10 \%)$ of overconditioned $(\mathrm{BCS} \geq 4)$ cows were presented in $42 \%$ of the farms. Most of the close-up (94\%) cow groups had $\geq 0.76 \mathrm{~m} /$ cow of feedbunk access (optimal option), and bunks were cleaned daily in $62 \%$ of those (Table $5)$. Less than one-third of the close-up cow groups had proper water access (Table 5). In $15 \%$ of the farms, the DCAD of close-up diet was not controlled; in $6 \%$ of the farms, a negative DCAD diet was offered and urine $\mathrm{pH}$ of the group was assessed weekly to monitor group acidification level. The majority of the farms (78\%) offered a diet balanced for minerals of major importance in transition or a negative DCAD diet without consistently monitoring urine $\mathrm{pH}$ (Table 5).

Pen Management. In the majority of the close-up (80\%) groups, cows were observed at least once daily (Table 6). In the close-up, three-fourths of the groups had $90 \%$ of their cows spending between 14 to $28 \mathrm{~d}$ in the close-up pen (Table 6). Less than half of the producers moved their close-up cows once per week in groups of 10 or more cows, whereas in $22 \%$ of the closeup groups cows were moved daily, individually, or at intervals greater than $7 \mathrm{~d}$ (Table 6). If the farm had a separated calving pen (nonexistent in 23 farms), in the majority $(63 \%)$ of the farms, cows were moved within $6 \mathrm{~h}$ of parturition, $9 \%$ were moved within $1 \mathrm{~d}$, and approximately one-third of the cows were moved between one and $9 \mathrm{~d}$ before the expected calving date or based on parturition signs (Table 6 ).

Housing and Cow Comfort. Most farms provided a BP pen (81\%), whereas $18 \%$ were housed in a FS pen (Table 7). In the FS pens, bedding and comfort of closeup cows could be improved in $43 \%$ of the farms; lunge access (obstructed head space; $<0.76 \times 0.76 \mathrm{~m}$ ) could improve in $36 \%$, and $86 \%$ of the stalls had appropriate dimensions (Table 7). In the close-up area, stocking density of FS pens could improve in $36 \%$ of the farms (80-100\% stocking density), whereas $64 \%$ of the farm kept the close-up cows with a stocking density below $80 \%$ (Table 7). Close-up cows in BP pens were overstocked in $56 \%$ of the farms $\left(<13.9 \mathrm{~m}^{2} /\right.$ cow $)$, with $18 \%$ having $<9.3 \mathrm{~m}^{2} /$ cow (Table 7 ). Overall, close-up cows were overstocked in approximately half of the farms $(52 \%)$. Lack of a proper and functioning heat abatement system was observed in $91 \%$ of close-up groups (Table 7). Dead-ends (one or more) were observed in $22 \%$ of the close-up housing facilities (Tables 7 ).

\section{Fresh Period, Including Maternity}

Feeding Management. Fresh cow ration sortability could be improved in $31 \%$ of the farms. A balanced
TMR was fed for ad libitum consumption in $77 \%$ of the fresh groups, but a partial or restricted access to the TMR was observed in $17 \%$, and the remaining proportion $(6 \%)$ had no TMR (e.g., hay and corn silage fed separately; Table 8). Energy and critical nutrients were excessive or deficient in $5 \%$ of the fresh cow diets; protein level and AA profiles could be improved in $17 \%$ of the farms. In most fresh cow pens, there was $\geq 0.76$ $\mathrm{m} /$ cow available at the feedbunk $(87 \%)$, and feedbunk was cleaned daily (85\%; Table 8 ). Water access and quality could be improved in $41 \%$ of the fresh cow pens (Table 8).

Pen Management. In almost all farms (>95\%), cows would spend $<1 \mathrm{~h}$ locked up for screening purposes and $<2 \mathrm{~h} / \mathrm{d}$ away from the home pen (Table 9 ). In $27 \%$ of the farms, cows were daily monitored with a complete physical exam, in $64 \%$ a less rigid daily monitor program was in place with a partial physical exam, and in $9 \%$ of the farms, the methods of screening for fresh cow for health issues were not systematically performed. In most of the farms, the newborn was removed from the dam within 2 to $12 \mathrm{~h}$ postpartum (59\%; Table 9). In $40 \%$ of the farms, colostrum cows were housed with hospital cows (Table 9).

Housing and Cow Comfort. In FS pens, stall dimensions could be improved in more than $50 \%$ of the farms; more than $80 \%$ had appropriate unobstructed head lunge space (Table 10). Bedding and comfort of FS was suboptimal in $>62 \%$ of the farms; with bedding moist, lack of cushion, or neck rail placement not allowing all cows to rest comfortably (Table 10). Considering both housing systems (FS and BP pens), fresh cows were overstocked in $48 \%$ of the farms (FS: $>80 \%$ stocking density; BP: $\left.<13.9 \mathrm{~m}^{2} / \mathrm{cow}\right)$. Heat stress abatement strategies could be improved in $85 \%$ of the fresh cow facilities and footing and flooring could be improved in half of the facilities (Table 10).

\section{DISCUSSION}

This work objectively describes the prevalence of transition cow management practices in Canadian dairy herds. Our results demonstrate that stocking density, water access, heat abatement, and ration sortability are among the biggest opportunities for improvement across far-off, close-up, and fresh cow groups. In our study, the far-off period seems to have the greatest room for improvement versus the close-up and fresh cow periods. When comparing the different transition phases (far-off, close-up, and fresh periods), the far-off and its management implications are the least studied (Nydam et al., 2017) and might partially explain the poorer management practices observed for this group. 


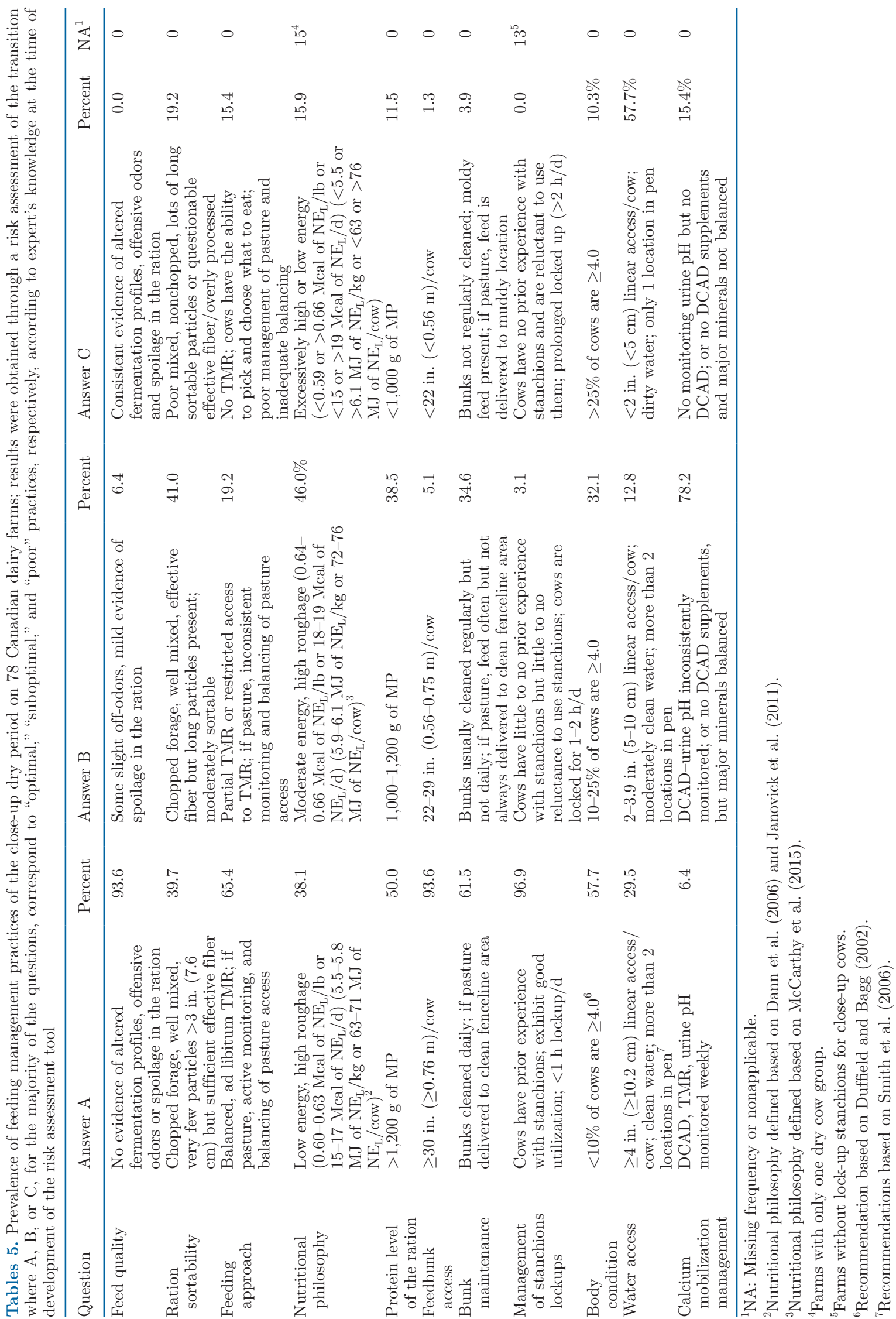




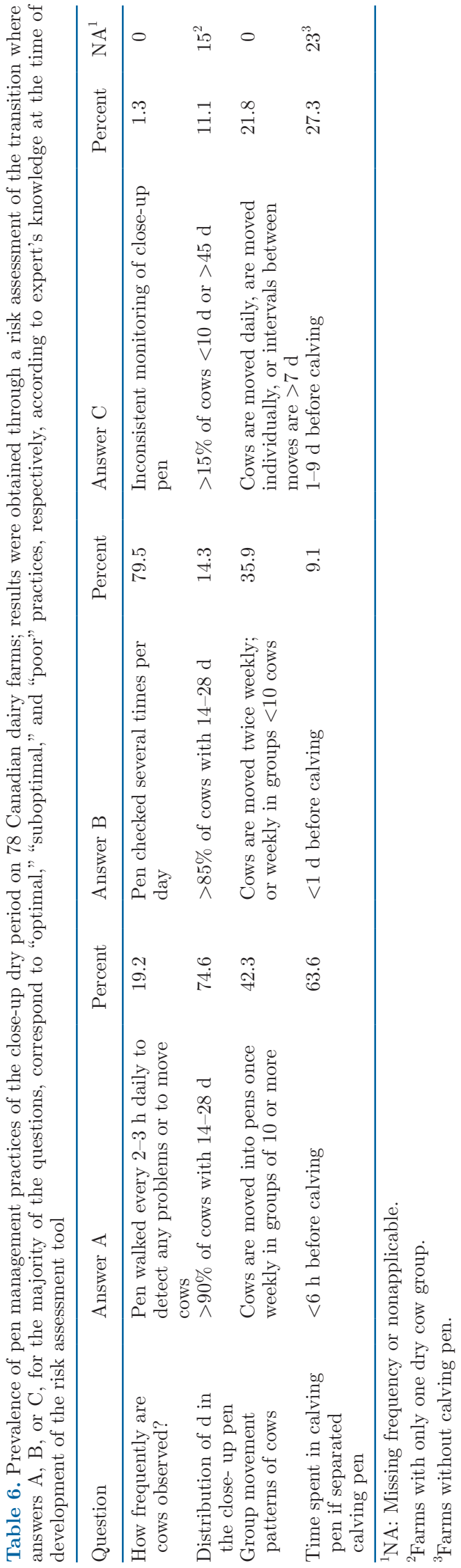

In previous qualitative research, Canadian dairy producers considered the unclear definition of "transition period" as a barrier for management improvement (Mills et al., 2020). The "transition period" is commonly defined as the period between 3 wk before (close-up) up to the first $3 \mathrm{wk}$ after parturition (Grummer, 1995), but many (Dann et al., 2006; Abuelo et al., 2021) highlight the importance of the far-off period for the subsequent lactation. Our study described existing management practices beyond the traditional definition of transition by including management from drying off until approximately 30 DIM (as designed by the developers of the risk assessment tool). The discussion will focus on the greatest opportunities identified from this study for improving nutrition, pen management, and housing environment.

\section{Nutritional Management of the Transition Period}

When assessing nutrition management, the focus should be, not only on diet formulation and preparation, but also consider actual intake (Grant and Dann, 2017; DeVries, 2019). In fact, eating behavior is more commonly the limiting factor for DMI than the dietary formulation itself (Grant and Dann, 2017). Producers can optimize DMI by controlling and adapting stocking density, grouping strategies, social interactions, and barn design (Grant and Albright, 2001).

It has been well documented that overcrowding and feedbunk competition compromise natural eating behavior and influence DMI (Albright, 1993; Mentink and Cook, 2006). As cattle increase in girth during pregnancy, the ideal linear bunk space must also increase. Thus, the recommended linear bunk space available per cow is greater in the dry period (minimum of $0.76 \mathrm{~m} / \mathrm{cow}$ in the transition group, Nordlund et al. (2006)) than mid to late lactation $(0.6 \mathrm{~m} / \mathrm{cow}$, National Farm Animal Care Council, 2009). Lockup stanchions help ensure the minimal space per cow at the feed bunk; they reduce competition and aggression at the bunk, and increase food access to submissive cows (Krawczel and Grant, 2008; DeVries, 2019). Sova et al. (2013) demonstrated an association between feed bunk length and milk characteristics (group-average milk fat increased by 0.06 percentage points and SSC decreased $13 \%$ with a $10 \mathrm{~cm} /$ cow increase). In our study, most farms had lockup stanchions in both the dry and in lactating periods. On these farms, cows and heifers were exposed to lockup stanchions before transition, which allows for good utilization of stanchions before the transition period. Although feed bunk access did not seem to be a major concern in our study, pen stocking density was not ideal (worst at the close-up, followed by fresh and 
Couto Serrenho et al.: DAIRY INDUSTRY TODAY

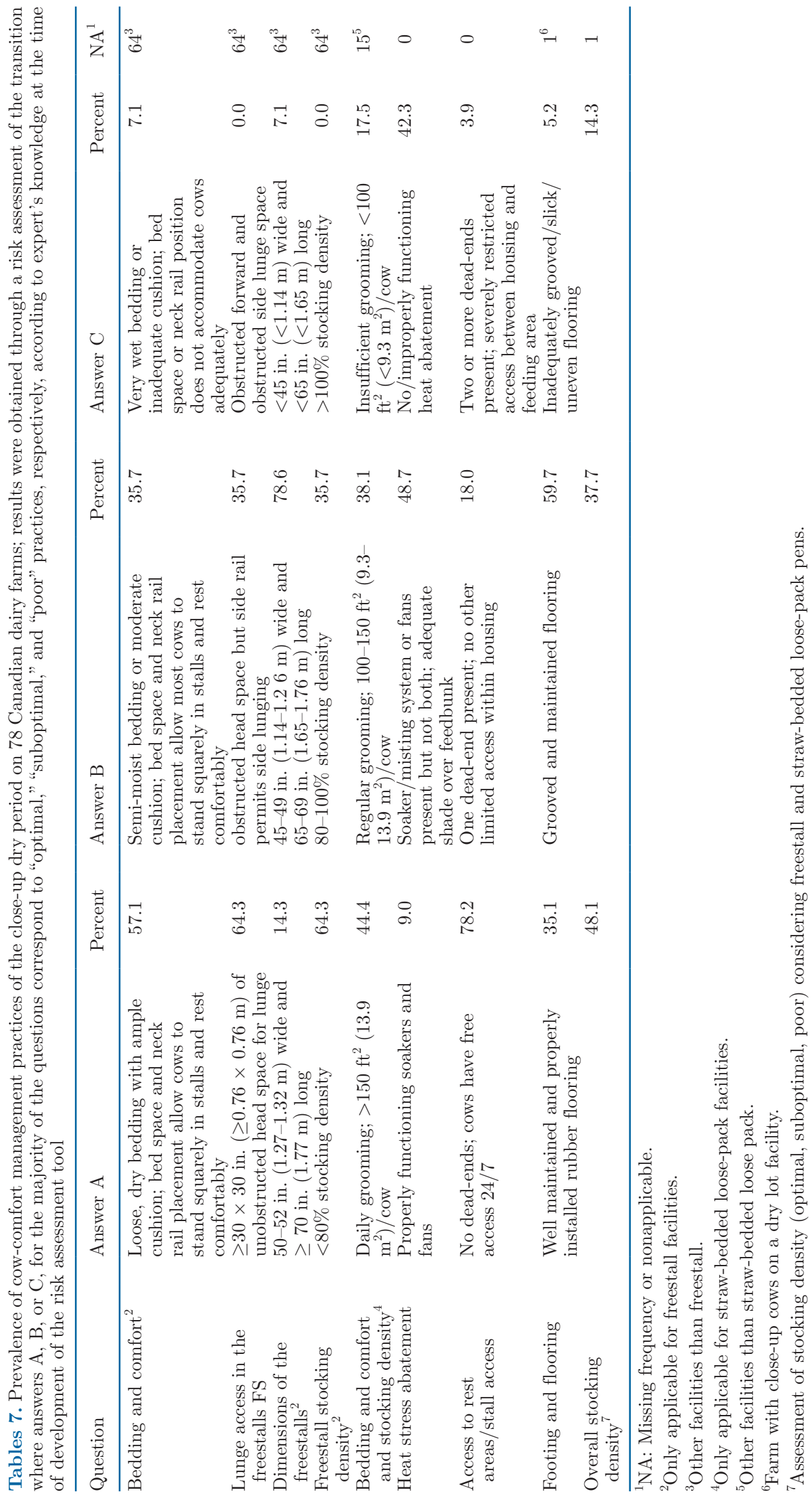


Couto Serrenho et al.: DAIRY INDUSTRY TODAY

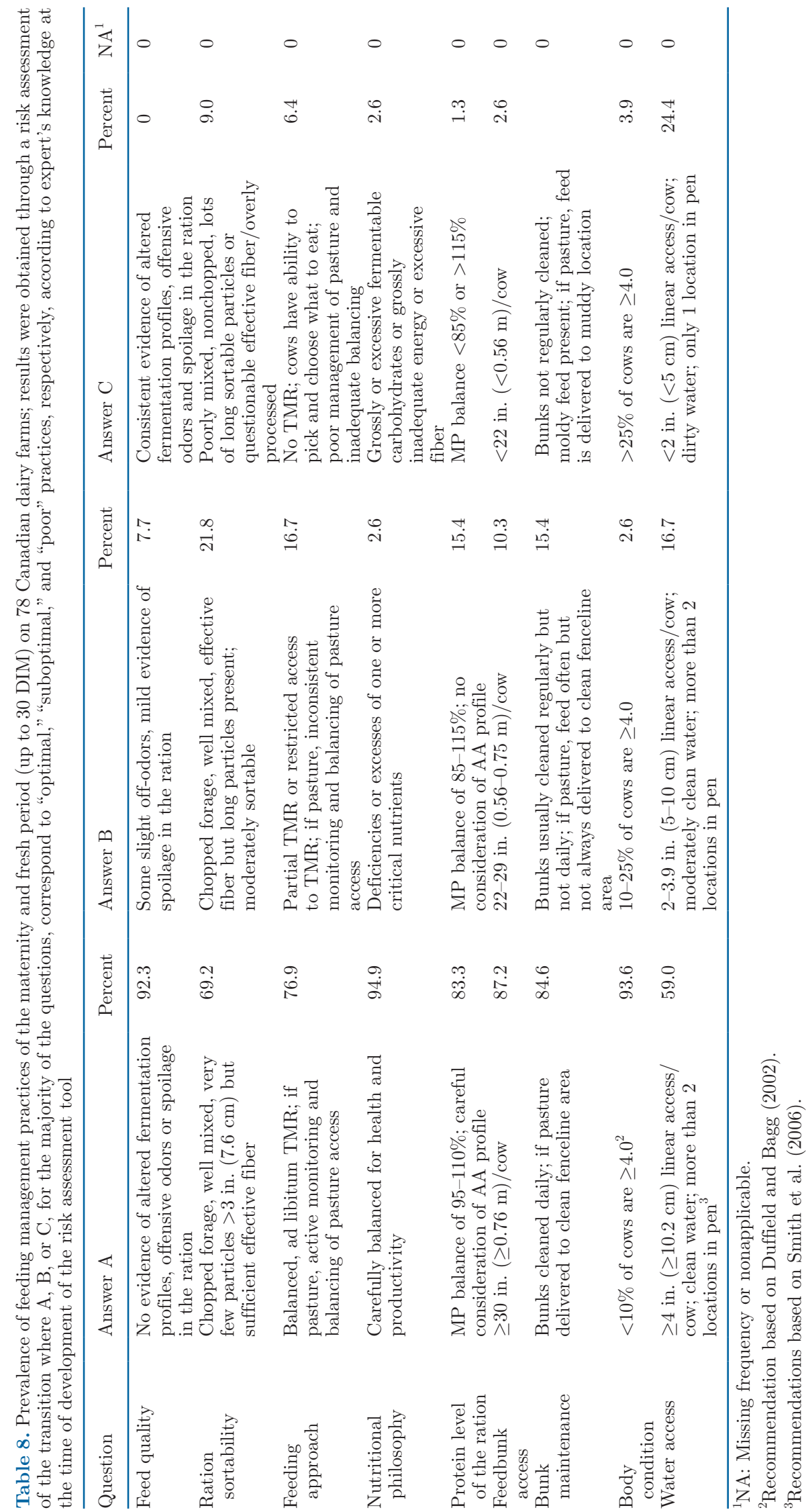


Couto Serrenho et al.: DAIRY INDUSTRY TODAY

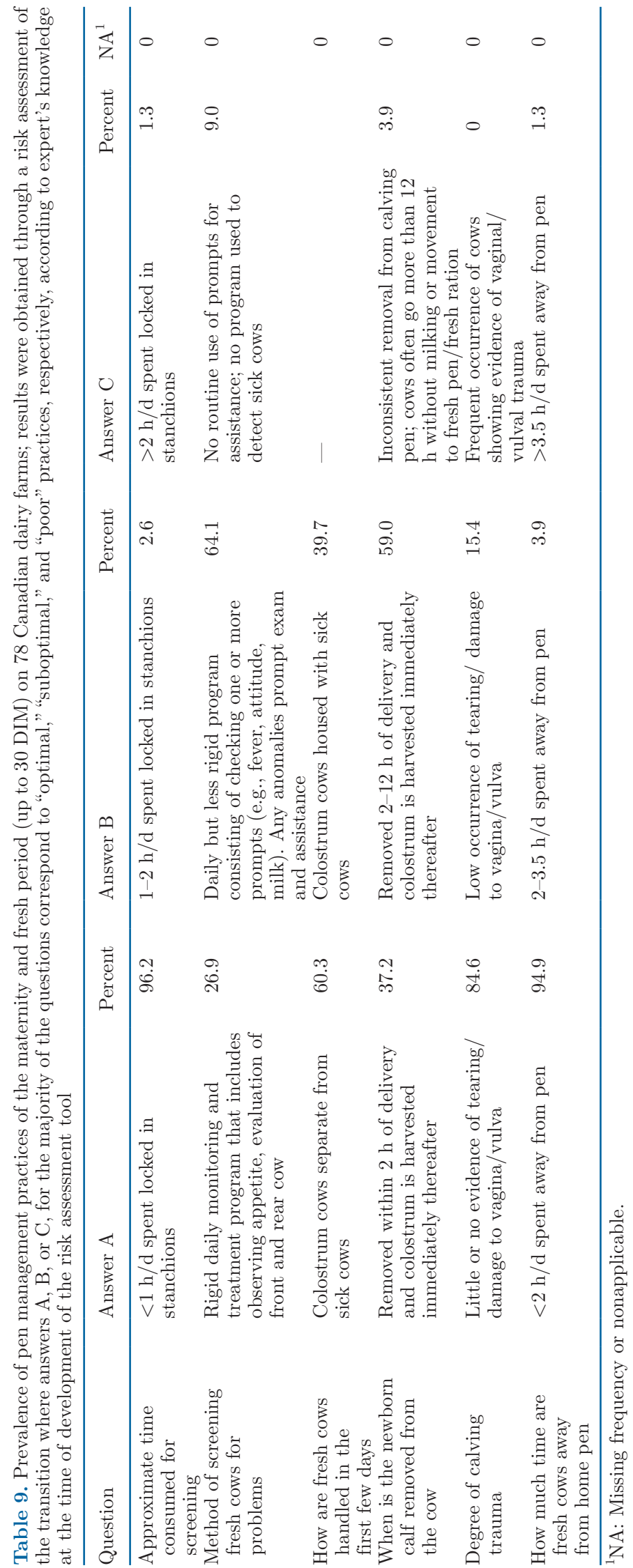




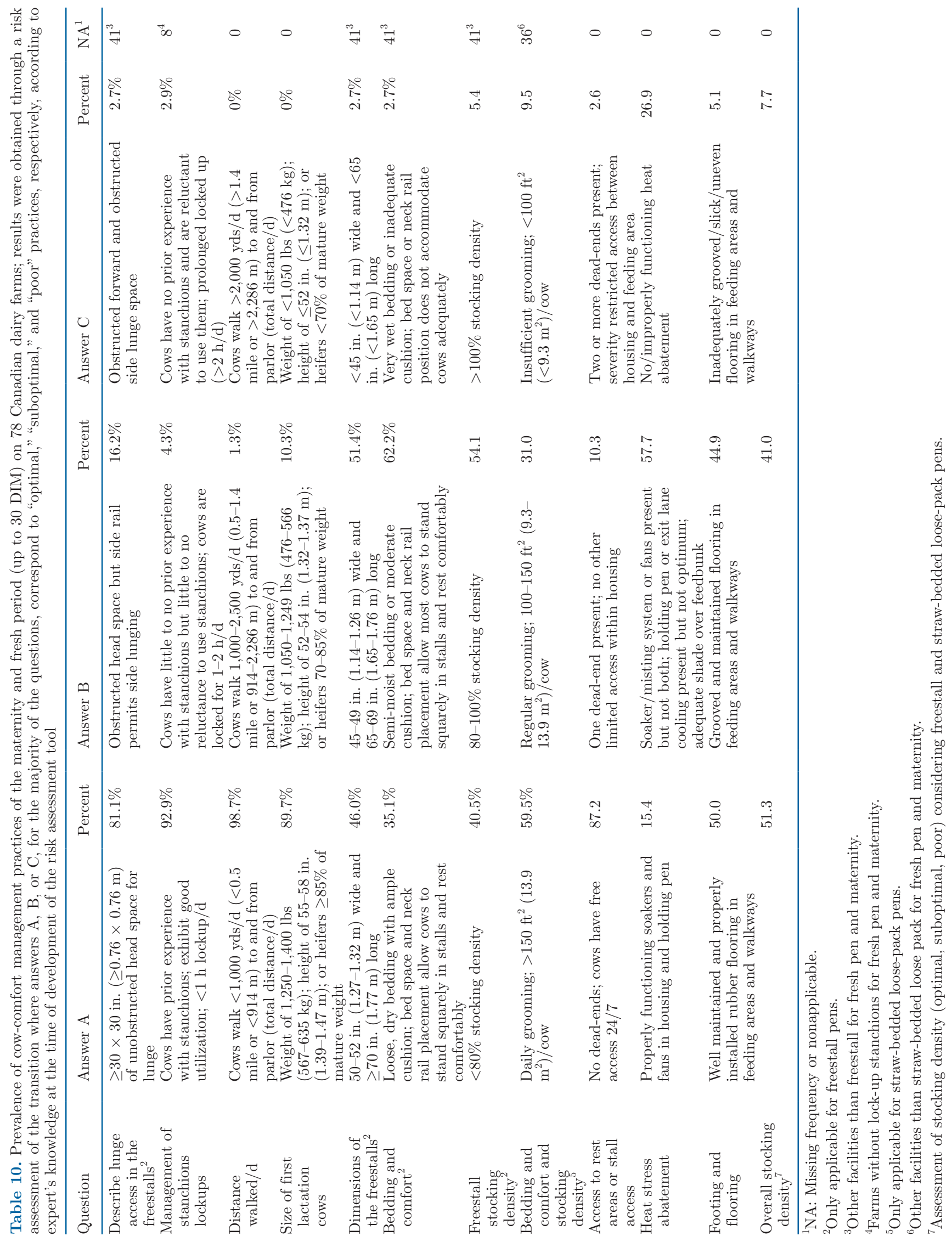


far-off periods). This topic is further discussed in the Cow Comfort section.

Ration sortability of the dry period (far-off and close-up) and fresh diets was observed in $>50 \%$ and $30 \%$ of the groups, respectively. Consequences of ration sortability and management strategies are reviewed by Miller-Cushon and DeVries (2017). When cows can choose TMR components (preference for small grain particles in detriment of effect fiber (Miller-Cushon and DeVries, 2017), rumen $\mathrm{pH}$ decreases, as well as rumination time, and DMI (Coon et al., 2018). In an overcrowded feed bunk, sorting by dominant cows for more palatable ingredients, leaves mostly long particles for submissive animals (generally, younger and smaller cows) (DeVries, 2019). Overall, sorting alters feeding behavior and DMI (dominant vs. submissive cows) (Olofsson, 1999; DeVries et al., 2005), milk yield and components (fat and protein; Sova et al., 2013; MillerCushon and DeVries, 2017; Coon et al., 2018), and health (e.g., greater risk for subacute ruminal acidosis; DeVries et al., 2008). For example, in 22 FS herds (cows with $187 \pm 47$ DIM; parity of $2.3 \pm 0.6$ ), for every $2 \%$ increase of long TMR particles sorting (top screen of Penn State Particle Separator; Heinrichs and Kononoff, 2006), milk yield decreased $1 \mathrm{~kg} / \mathrm{d}$ (Sova et al., 2013).

Water is the most important nutrient for dairy cows and affects the welfare, health, and performance of dairy cows throughout the lactation cycle (Murphy, 1992; NRC, 2001). Yet, we demonstrated that its quality and availability are not ideal $(\geq 10.2 \mathrm{~cm} /$ cow linear access, clean water, and more than 2 locations in pen) during the dry and fresh periods on the studied farms. Having at least 2 water bowls in the pen was supported by (Andersson, 1987). The author compared drinking frequency of cows $(\mathrm{n}=32$ multiparous cows; 8 cows/ bowl) placed in equal pens where waterers were placed closely $(0.9 \mathrm{~m})$ versus apart $(22 \mathrm{~m})$ and concluded that drinking bouts per cow/day were greater in the latter ( 7 vs. 8 bouts/d, respectively). It is recommended that the number of water sources in a pen follow the number of social groups (2 water sources per social group; Jones and Kammel, 2017). In groups with less than 100 cows (1 social group), water should be located at least in 2 locations in a pen; in pens with 100 to 200 cows, ideally, the pen will have 4 waterers (Jones and Kammel, 2017). To allow the greatest number of cows to drink at the same time, it is recommended that a minimum of $10 \mathrm{~cm}$ (4 in.) per cow be available (Jones and Kammel, 2017). In a literature review regarding water intake, Jensen and Vestergaard (2021) refer to the need for studies assessing the relationship between water availability (waterer length and placement), stocking density, welfare, and productivity to assess current recommendation.
In our study, $15 \%$ of the farms did not did not balance close-up diets for major essential minerals or supplement with anionic salts (negative DCAD) in an effort to manage calcium metabolism, and only $6 \%$ mentioned using anionic supplements with cow's urine $\mathrm{pH}$ monitored weekly. Routine evaluation of urine $\mathrm{pH}$ average and variation is critical to control acidification level as well TMR mixing or sorting issues (Charbonneau et al., 2006; Goff, 2008). However, prepartum urine pH assessment can be time consuming, even more so without appropriate facilities to lockup cows. This, in most cases, explains why producers might not use anionic supplementation. The DCAD should first be controlled by balancing minerals (e.g., K, Na, P), followed by anionic supplements [e.g., chloride $\left(\mathrm{Cl}^{-}\right)$can be added] when not possible to achieve the targeted DCAD with the available feed ingredients (Goff, 2008). Despite the extra labor and time needed to control acidification, health and performance benefits of prepartum negative DCAD diets seem to be clear for adult cows (Couto Serrenho et al., 2021a). However, the effects in first lactation cows are still unclear (Lean et al., 2019). The increased time to pregnancy observed in primiparous cows after exposure to a negative DCAD diet (DCAD: -108 vs. $+105 \mathrm{mEq} / \mathrm{kg}$ of DM; Couto Serrenho et al., 2021b) raised questions about the overall benefits of prepartum negative DCAD diets when prepartum heifers and adult cows are housed together. Overall, our data demonstrate that there is opportunity for better adoption of nutritional strategies to manage calcium metabolism.

\section{Pen Management and Grouping Strategies}

In our study, most farms had $<75 \%$ of their cows dry during 40 to $70 \mathrm{~d}$ and had 2 dry-cow groups. Although less prevalent for the far-off management area than the close-up and fresh areas, heifers and mature cows were commonly housed together. Separate grouping for heifers and cows might be beneficial because of their different nutritional needs throughout the transition period (far-off, close-up, and lactating; NRC, 2001). In addition, regrouping has been shown to be more stressful for heifers than mature cows; social hierarchy, competition, and previous experience with regrouping help make it less detrimental on older animals (Soonberg et al., 2021). However, group sizes and housing constraints might not allow or justify segregation by age groups or by dry stage (far-off and close-up periods; Jones and Kammel, 2014).

In smaller herds, one dry group might be a more reasonable and economic option. However, a close-up group might still be beneficial to allow targeted supple- 
mentation for prepartum cows (e.g., anion or rumenprotected choline supplementation) or potentially for improved rumen adaptation to a lactating cow diet, particularly if no fresh diet exists on the farm.

Cow-calf separation is a controversial topic within the dairy industry and the different options generate controversy among researchers, producers, consultants, and consumers. Most farms (59\%) included in our study removed the calf from the dam within 2 to $12 \mathrm{~h}$ after birth. Among the advantages of early cow-calf separation is the minimization of stress caused by separation (Weary and Chua, 2000), avoiding exposure of the newborn to the dam's environment to reduce the risk of infectious diseases (Marcé et al., 2011), and increasing the amount of saleable milk (otherwise consumed by the calf; Wagenaar and Langhout, 2007). However, in a systematic review, Beaver et al. (2019) reported a lack of evidence regarding better calf health (scour, pneumonia, or successful passive transfer of IgG) or lower risk of Johne's disease with early cow-calf separation. Most dairy consumers do not support early cow-calf separation (Boogaard et al., 2011; Busch et al., 2017), and keeping cow and calf together for longer periods has shown some health benefits for the cow (udder and uterine health) and calf (greater average daily gain and fewer diarrhea treatments; Weary and Chua, 2000; Krohn, 2001; Meagher et al., 2019). More research is required to fully evaluate the relative merits of both management practices.

\section{Housing and Cow Comfort}

It is well recognized that housing and overall management are as important as the dietary composition for cow's well-being and herd health and performance (Krawczel and Grant, 2008; DeVries, 2019). In terms of facilities, our results suggest that heat abatement strategies, cow comfort, and stocking density can all be better addressed on farms.

Heat stress continues to affect the dairy industry and reduces well-being, production, and reproductive performance (Polsky and von Keyserlingk, 2017). In a literature review, Polsky and von Keyserlingk (2017) addressed the detrimental effects of elevated environmental temperatures on affective states, behavior, biological function, and health. Heat abatement strategies help to mitigate the effect of the environmental conditions on transition dairy cows' health, production, and reproductive performance (Becker and Stone, 2020). Among different options, Correa-Calderon et al. (2004) concluded that combined fans and sprinklers provide a more effective heat stress control (reduction of body temperature and heart rate). In our study, a lack of proper heat stress abatement strategies (absence of properly functioning soakers, fans, or both) was observed in all groups, but the far-off seems to be the most affected period.

Stocking density can be assessed by feed bunk length, the surface of the lying area, or the ratio of cows to stalls (FS barn; De Vries et al., 2016). Overstocking is associated with lameness severity (King et al., 2016), reduction of DMI (especially in submissive cows; DeVries, 2019), milk yield (Bach et al., 2008), fertility (Schefers et al., 2010), and overall production efficiency (De Vries et al., 2016).

Maximizing utilization of the facilities without compromising welfare, health, and productivity is the overall goal to achieve better economic performance (De Vries et al., 2016). The optimal stocking density varies along the lactation cycle and is sensitive to milk prices and observed milk losses (De Vries et al., 2016). In our study, the ideal stocking density for close-up and fresh groups was set at $<100 \%$ for far-off and at $<80 \%$ for close-up periods. Increased prepartum stocking density is associated with more subclinical ketosis in the first week of lactation (Goldhawk et al., 2009) and milk production is reduced. In fact, in first lactation animals, for each $10 \%$ stocking density increase above the $80 \%$ in the close-up period was observed a $0.7 \mathrm{~kg} / \mathrm{d}$ milk yield reduction (Oetzel et al., 2007). When commingling, heifers are more affected than older cows (De Vries et al., 2016). This might be explained by the fact that heifer are smaller and more likely submissive than older cows (Silva et al., 2014). Thus, when mature cows and heifers are housed together it is recommended that the stocking density does not surpass $80 \%$ stall occupancy in the prepartum period (Oetzel et al., 2007). Silva et al. (2014) did not observe detrimental effects on health, production, or reproductive performance when evaluating $80 \%$ versus $100 \%$ stocking density in prepartum pens (FS) in Jersey cows segregated by parity (nulliparous cows, $\mathrm{n}=154$; parous cows, $\mathrm{n}=184$ ). Optimal stocking density for the prepartum period might vary depending on, for example, grouping strategies, breed, and feedbunk space available. Although transition cows need more space (DeVries, 2019), mid- to late-lactation cows in FS pens can be stocked up to $120 \%$ without compromising natural behavior and welfare (Krawczel and Grant, 2009).

The introduction of a new animal to the group is a stressful event for both the cows in the existing group and the new cows, especially in submissive animals (Lamb, 1976; Nydam et al., 2017). Although moving cows between pens is an inevitable and necessary management practice, stress events and magnitude caused by adapting the social hierarchy should be avoided as much as possible. Thus, the number of pen movements should be kept at a bare minimum (Lamb, 1976) and 
cows should be moved in groups of 3 to 5 cows, which is thought to cause less stress than moving cows individually (Cook and Nordlund, 2004).

When designing pen movement, grouping, and housing, it is a common mistake to consider the average number of calvings rather than extremes when defining the size of the pens. Jones and Kammel (2014) recommended building the pens considering the pen space needed for $90 \%$ of the year (small adjustments can be made for the remaining $10 \%$ of the time) or, when no data are available, design it to accommodate $140 \%$ of the average number of calvings per week. When the facilities do not account for the fluctuating number of calvings over time, producers tend to sacrifice space for far-off cows to provide more space for close-up cows or vice versa. This may lead to overcrowding of far-off cows and late movements from the far-off to the closeup pen. In this case, close-up cows, instead of being exposed to the close-up diet and environment for at least 2 wk before parturition, have their stressors occurring closer to the beginning of lactation.

\section{Final Considerations and Limitations of the Study}

The participating farms were selected based on a convenience sample through requests by the herd veterinarian. Both poor (often initiated by the veterinarian) and exceptionally managed (often initiated by the producer) farms were the most likely to request a risk assessment on their farms. Although we cannot eliminate the presence of selection bias in our study, the presence of an equal chance of better versus lesser management helps balance our sample population. Most farms were located in Ontario, thus extrapolation of the results to a larger geographic area should be made with caution. Some degree of selection bias should also be considered because farms were only included if the owner allowed the use of their data. Considering that the risk assessment tool was performed by independent consultants and that the producer wanted a true evaluation of their management, we do not expect significant information bias.

The fact that, in the risk assessment tool, tiestall farms were entered as FS facilities (absence of the tiestall option in the risk assessment tool) might have contributed to a lack of detail regarding this particular housing system prevalent in Ontario and Quebec provinces (Agriculture and Agri-Food Canada, 2020).

The results of this study indicate that there is opportunity to improve management throughout the dry and fresh periods. Among the 3 areas studied (far-off, closeup, and fresh periods), the far-off group parameters showed the most room for improvement. Although we have identified the most common flaws of transition cow management, dairy consultants need to consider that on each farm, identification of management opportunities and priorities should arise from a complete and thorough transition period assessment. The risk assessment tool used in this study was designed based on both published literature and expert opinion. Due to the lack of field trials assessing welfare, health, production, and economic outcomes from each management practice, the definition of "optimal" or "suboptimal" should be interpreted with caution. Transition management is farm-specific and deserves a unique approach considering herd characteristics, facilities, economics, and producer's beliefs and motivations with the final aim of setting new goals and promoting change.

Future research should consider an assessment of the effect of these management practices on health and performance at the herd and individual cow levels. Demonstrating direct effects of management practices on disease, milk yield, or both would provide greater evidence of the link between management, performance, and economics and would help to define management priorities on a dairy farm.

\section{CONCLUSIONS}

The use of objective tools to assess transition cow management on-farm helps to facilitate in identifying the areas with the greatest overall opportunity for improvement. Among those highlighted in this study include stocking density, water access and availability, heat abatement strategies, and sorting of the rations across far-off, close-up, and fresh periods. This work brings awareness to some areas of opportunity in transition cow management practices, which can help dairy veterinarians, consultants, and producers assess transition management of dairy farms and define transition management bottlenecks. Future research should evaluate the effect of management practices on individual and overall herd performance.

\section{ACKNOWLEDGMENTS}

The authors thank OMAFRA Alliance (Guelph, Canada) for funding, Elanco (Greenfield, IN) and CanWest DHI (Guelph, Canada) for in kind support, and dairy producers for sharing their data. The authors have not stated any conflicts of interest.

\section{REFERENCES}

Abuelo, A., L. Wisnieski, J. L. Brown, and L. M. Sordillo. 2021. Rumination time around dry-off relative to the development of diseases in early-lactation cows. J. Dairy Sci. 104:5909-5920. https://doi .org/10.3168/jds.2020-19782. 
Agriculture and Agric-Food Canada. 2020. Dairy Barns by Type in Canada. Accessed May 26, 2021. http://www5.agr.gc.ca/ resources/prod/dairy/pdf/barn_types_e.pdf.

Albright, J. L. 1993. Feeding behavior of dairy cattle. J. Dairy Sci. 76:485-498. https://doi.org/10.3168/jds.S0022-0302(93)77369-5.

Andersson, M. 1987. Effects of number and location of water bowls and social rank on drinking behaviour and performance of loosehoused dairy cows. Appl. Anim. Behav. Sci. 17:19-31. https://doi .org/10.1016/0168-1591(87)90004-9.

Bach, A., N. Valls, A. Solans, and T. Torrent. 2008. Associations between nondietary factors and dairy herd performance. J. Dairy Sci. 91:3259-3267. https://doi.org/10.3168/jds.2008-1030.

Beaver, A., R. K. Meagher, M. A. G. von Keyserlingk, and D. M. Weary. 2019. Invited review: A systematic review of the effects of early separation on dairy cow and calf health. J. Dairy Sci. 102:5784-5810. https://doi.org/10.3168/jds.2018-15603.

Becker, C. A., and A. E. Stone. 2020. Graduate Student Literature Review: Heat abatement strategies used to reduce negative effects of heat stress in dairy cows. J. Dairy Sci. 103:9667-9675. https:// doi.org/10.3168/jds.2020-18536.

Boogaard, B. K., B. B. Bock, S. J. Oosting, J. S. C. Wiskerke, and A. J. van der Zijpp. 2011. Social acceptance of dairy farming: The ambivalence between the two faces of modernity. J. Agric. Environ. Ethics 24:259-282. https://doi.org/10.1007/s10806-010 $-9256-4$

Busch, G., D. M. Weary, A. Spiller, and M. A. G. von Keyserlingk. 2017. American and German attitudes towards cow-calf separation on dairy farms. PLoS One 12:e017413. https://doi.org/10.1371/ journal.pone.0174013.

Charbonneau, E., D. Pellerin, and G. R. Oetzel. 2006. Impact of lowering dietary cation-anion difference in nonlactating dairy cows: A meta-analysis. J. Dairy Sci. 89:537-548. https://doi.org/10.3168/ jds.S0022-0302(06)72116-6.

Cook, N. B., and K. V. Nordlund. 2004. Behavioral needs of the transition cow and considerations for special needs facility design. Vet. Clin. North Am. Food Anim. Pract. 20:495-520. https://doi.org/ 10.1016/j.cvfa.2004.06.011.

Cooke, M. R. 1991. Experts in Uncertainty: Opinion and Subjective Probability in Science. Oxford University Press.

Coon, R. E., T. F. Duffield, and T. J. DeVries. 2018. Effect of straw particle size on the behavior, health, and production of early-lactation dairy cows. J. Dairy Sci. 101:6375-6387. https://doi.org/10 .3168/jds.2017-13920.

Correa-Calderon, A., D. Armstrong, D. Ray, S. DeNise, M. Enns, and C. Howison. 2004. Thermoregulatory responses of Holstein and Brown Swiss Heat-Stressed dairy cows to two different cooling systems. Int. J. Biometeorol. 48:142-148. https://doi.org/10.1007/ s00484-003-0194-y.

Couto Serrenho, R. 2021. Supplemental Figure S1. Description of data preparation steps for a retrospective descriptive study of environment, nutrition, and management practices for far-off, close-up, and fresh cows on 78 Canadian dairy farms. Mendeley Data, V1. https://doi.org/10.17632/krn357zs6r.1.

Couto Serrenho, R., T. C. Bruinjé, E. I. Morrison, T. J. DeVries, T. F. Duffield, and S. J. LeBlanc. 2021a. Controlled trial of the effect of negative dietary cation-anion difference on postpartum health of dairy cows. J. Dairy Sci. 104:6929-6943. https://doi.org/10.3168/ jds.2020-19389.

Couto Serrenho, R., T. C. Bruinjé, E. I. Morrison, T. J. DeVries, T. F. Duffield, and S. J. LeBlanc. 2021b. Controlled trial of the effect of negative dietary cation-anion difference prepartum diets on milk production, reproductive performance, and culling of dairy cows. J. Dairy Sci. 104:6919-6928. https://doi.org/10.3168/jds $.2020-19390$

Dairy Farmers of Canada. 2021. ProAction: Animal care. Accessed May 26, 2021. https://www.dairyfarmers.ca/proaction/resources/ animal-care.

Dann, H. M., N. B. Litherland, J. P. Underwood, M. Bionaz, A. D'Angelo, J. W. McFadden, and J. K. Drackley. 2006. Diets during far-off and close-up dry periods affect periparturient metabolism and lactation in multiparous cows. J. Dairy Sci. 89:3563-3577. https://doi.org/10.3168/jds.S0022-0302(06)72396-7.

De Vries, A., H. Dechassa, and H. Hogeveen. 2016. Economic evaluation of stall stocking density of lactating dairy cows. J. Dairy Sci. 99:3848-3857. https://doi.org/10.3168/jds.2015-10556.

DeVries, T. J. 2019. Feeding behavior, feed space, and bunk design and management for adult dairy cattle. Vet. Clin. North Am. Food Anim. Pract. 35:61-76. https://doi.org/10.1016/j.cvfa.2018 .10.003.

DeVries, T. J., F. Dohme, and K. A. Beauchemin. 2008. Repeated ruminal acidosis challenges in lactating dairy cows at high and low risk for developing acidosis: Feed sorting. J. Dairy Sci. 91:39583967. https://doi.org/10.3168/jds.2008-1347.

DeVries, T. J., M. A. G. von Keyserlingk, and K. A. Beauchemin. 2005. Frequency of feed delivery affects the behavior of lactating dairy cows. J. Dairy Sci. 88:3553-3562. https://doi.org/10.3168/ jds.S0022-0302(05)73040-X.

Duffield, T., and R. Bagg. 2002. Herd level indicators for the prediction of high-risk dairy herds for subclinical ketosis. Pages 175-176 in Proc Am Assoc Bov Pract, Madison, WI. Frontier Printers, Inc.

Elanco. 2013. Vital 90 Days Analyzer - dRisk. Accessed Aug. 8, 2021 https://apps.apple.com/us/app/id631489592.

Ferguson, J. D., D. T. Galligan, and N. Thomsen. 1994. Principal descriptors of body condition score in Holstein cows. J. Dairy Sci. 77:2695-2703. https://doi.org/10.3168/jds.S0022-0302(94)77212 $-\mathrm{X}$.

Goff, J. P. 2008. The monitoring, prevention, and treatment of milk fever and subclinical hypocalcemia in dairy cows. Vet. J. 176:50-57. https://doi.org/10.1016/j.tvjl.2007.12.020.

Goldhawk, C., N. Chapinal, D. M. Veira, D. M. Weary, and M. A. G. von Keyserlingk. 2009. Prepartum feeding behavior is an early indicator of subclinical ketosis. J. Dairy Sci. 92:4971-4977. https:/ /doi.org/10.3168/jds.2009-2242.

Grant, R. J., and J. L. Albright. 2001. Effect of animal grouping on feeding behavior and intake of dairy cattle. J. Dairy Sci. 84:E156E163. https://doi.org/10.3168/jds.S0022-0302(01)70210-X.

Grant, R. J., and H. M. Dann. 2017. Nutrition and Nutritional Management. 3rd ed. FASS Inc., ed. American Dairy Science Association.

Grummer, R. R. 1995. Impact of changes in organic nutrient metabolism on feeding the transition dairy cow. J. Anim. Sci. 73:28202833. https://doi.org/10.2527/1995.7392820x.

Heinrichs, J., and P. Kononoff. 2006. Evaluating Particle Size of Forages and TMRs Using the New Penn State Forage Particle Separator. Penn State College of Agricultural Sciences, Cooperative Extension. Accessed Aug. 8, 2021. https://edisciplinas.usp.br/ pluginfile.php/380702/mod_folder/content/0/3.4 - Heinrichs and Kononoff (2002) - Evaluating particle size of forages and TMRs using the New Penn State Separator.pdf?forcedownload=1.

Janovick, N. A., Y. R. Boisclair, and J. K. Drackley. 2011. Prepartum dietary energy intake affects metabolism and health during the periparturient period in primiparous and multiparous Holstein cows 1. J. Dairy Sci. 94:1385-1400. https://doi.org/10.3168/jds .2010-3303.

Jensen, M. B., and M. Vestergaard. 2021. Invited review: Freedom from thirst-Do dairy cows and calves have sufficient access to drinking water? J. Dairy Sci. https://doi.org/10.3168/jds.2021 $-20487$.

Jones, G. A., and D. W. Kammel. 2014. Facility design to optimize transition cow comfort with emphasis on confinement systems. Pages 104-115 in Dairy Cattle Reproduction Conference, Salt Lake City, UT.

Jones, G. A., and D. W. Kammel. 2017. Large dairy herd design and systems in temperate and cold climates. Pages 71-82 in Large Dairy Herd Management. 3rd ed. American Dairy Science Association.

King, M. T. M., E. A. Pajor, S. J. LeBlanc, and T. J. DeVries. 2016. Associations of herd-level housing, management, and lameness prevalence with productivity and cow behavior in herds with automated milking systems. J. Dairy Sci. 99:9069-9079. https://doi .org/10.3168/jds.2016-11329. 
Krawczel, P., and R. Grant. 2008. Standing room only: Effects of overcrowding. Pages $8-15$ in NMC Regional Meeting Proceedings. National Mastitis Council.

Krawczel, P., and R. Grant. 2009. Effects of cow comfort on milk quality, productivity and behavior. Pages 15-24 in NMC Annu. Meet. Proc. National Mastitis Council.

Krohn, C. C. 2001. Effects of different suckling systems on milk production, udder health, reproduction, calf growth and some behavioural aspects in high producing dairy cows - A review. Appl. Anim. Behav. Sci. 72:271-280. https://doi.org/10.1016/S0168 -1591(01)00117-4.

Lamb, R. C. 1976. Relationship between cow behavior patterns and management systems to reduce stress. J. Dairy Sci. 59:1630-1636. https://doi.org/10.3168/jds.S0022-0302(76)84416-5.

Lean, I. J., J. E. P. Santos, E. Block, and H. M. Golder. 2019. Effects of prepartum dietary cation-anion difference intake on production and health of dairy cows: A meta-analysis. J. Dairy Sci. 102:21032133. https://doi.org/10.3168/jds.2018-14769.

Marcé, C., P. Ezanno, H. Seegers, D. U. Pfeiffer, and C. Fourichon. 2011. Within-herd contact structure and transmission of Mycobacterium avium subspecies paratuberculosis in a persistently infected dairy cattle herd. Prev. Vet. Med. 100:116-125. https://doi.org/10 .1016/j.prevetmed.2011.02.004.

McCarthy, M. M., T. Yasui, C. M. Ryan, S. H. Pelton, G. D. Mechor, and T. R. Overton. 2015. Metabolism of early-lactation dairy cows as affected by dietary starch and monensin supplementation. J. Dairy Sci. 98:3351-3365. https://doi.org/10.3168/jds.2014-8821.

Meagher, R. K., A. Beaver, D. M. Weary, and M. A. G. von Keyserlingk. 2019. Invited review: A systematic review of the effects of prolonged cow-calf contact on behavior, welfare, and productivity. J. Dairy Sci. 102:5765-5783. https://doi.org/10.3168/jds.2018 $-16021$.

Mentink, R. L., and N. B. Cook. 2006. Short communication: Feed bunk utilization in dairy cows housed in pens with either two or three rows of free stalls. J. Dairy Sci. 89:134-138. https://doi.org/ 10.3168/jds.S0022-0302(06)72076-8.

Miller-Cushon, E. K., and T. J. DeVries. 2017. Feed sorting in dairy cattle: Causes, consequences, and management. J. Dairy Sci. 100:4172-4183. https://doi.org/10.3168/jds.2016-11983.

Mills, K. E., D. M. Weary, and M. A. G. von Keyserlingk. 2020. Identifying barriers to successful dairy cow transition management. J. Dairy Sci. 103:1749-1758. https://doi.org/10.3168/jds.2018-16231.

Murphy, M. R. 1992. Water metabolism of dairy cattle. J. Dairy Sci 75:326-333. https://doi.org/10.3168/jds.S0022-0302(92)77768-6.

National Farm Animal Care Council. 2009. Code of Practice for the Care and Handling of Dairy Cattle: Review of Scientific Research on Priority Issues. Accessed Aug. 8, 2021. https://www.nfacc.ca/ pdfs/codes/dairy_code_of_practice.pdf.

Nordlund, K., N. Cook, and G. Oetzel. 2006. Commingling Dairy Cows: Pen Moves, Stocking Density, and Health. Pages 36-42 in 39th Proceedings American Association Bovine Practitioners, St. Paul, MN. American Association Bovine Practitioners.

NRC (National Research Council). 2001. Nutrient Requirements of Dairy Cattle. 7th rev. ed. The National Academies Press.

Nydam, D. V., T. R. Overton, J. A. A. McArt, M. M. McCarthy, B. Leno, and S. Mann. 2017. Management of transition cows to optimize health and production. Pages 1067-1076 in Large Dairy Herd Management. 3rd ed. American Dairy Science Association.

O'Connor, A. M., J. M. Sargeant, I. R. Dohoo, H. N. Erb, M. Cevallos, M. Egger, A. K. Ersbøll, S. W. Martin, L. R. Nielsen, D. L. Pearl,
D. U. Pfeiffer, J. Sanchez, M. E. Torrence, H. Vigre, C. Waldner, and M. P. Ward. 2016. Explanation and elaboration document for the STROBE-Vet statement: Strengthening the reporting of observational studies in epidemiology - Veterinary Extension. J. Vet. Intern. Med. 30:1896-1928. https://doi.org/10.1111/jvim.14592.

Oetzel, G. R., K. M. Emery, W. P. Kautz, and J. E. Nocek. 2007. Direct-fed microbial supplementation and health and performance of pre- and postpartum dairy cattle: A field trial. J. Dairy Sci. 90:2058-2068. https://doi.org/10.3168/jds.2006-484.

Olofsson, J. 1999. Competition for total mixed diets fed for ad libitum intake using one or four cows per feeding station. J. Dairy Sci. 82:69-79. https://doi.org/10.3168/jds.S0022-0302(99)75210-0.

Overton, T. R., and M. R. Waldron. 2004. Nutritional management of transition dairy cows: Strategies to optimize metabolic health. J. Dairy Sci. 87:E105-E119. https://doi.org/10.3168/jds.S0022 -0302(04)70066-1.

Polsky, L., and M. A. G. von Keyserlingk. 2017. Invited review: Effects of heat stress on dairy cattle welfare. J. Dairy Sci. 100:8645-8657. https://doi.org/10.3168/jds.2017-12651.

Schefers, J. M., K. A. Weigel, C. L. Rawson, N. R. Zwald, and N. B. Cook. 2010. Management practices associated with conception rate and service rate of lactating Holstein cows in large, commercial dairy herds. J. Dairy Sci. 93:1459-1467. https://doi.org/10 .3168/jds.2009-2015.

Silva, P. R. B., A. R. Dresch, K. S. Machado, J. G. N. Moraes, K. Lobeck-Luchterhand, T. K. Nishimura, M. A. Ferreira, M. I. Endres, and R. C. Chebel. 2014. Prepartum stocking density: Effects on metabolic, health, reproductive, and productive responses. J. Dairy Sci. 97:5521-5532. https://doi.org/10.3168/jds.2014-8093.

Smith, J. F., M. J. Brouk, J. P. H. Iii, and K. C. Dhuyvetter. 2006. Issues with Dairy Facilities Located in the High Plains. Pages 1-14 in High Plains Dairy Conference.

Soonberg, M., M. Kass, T. Kaart, R. Barraclough, M. J. Haskell, and D. R. Arney. 2021. Effect of grouping on behaviour of dairy heifers and cows in the transition period. J. Dairy Res. 88:45-51. https:/ /doi.org/10.1017/S0022029921000066.

Sova, A. D., S. J. LeBlanc, B. W. McBride, and T. J. DeVries. 2013. Associations between herd-level feeding management practices, feed sorting, and milk production in freestall dairy farms. J. Dairy Sci. 96:4759-4770. https://doi.org/10.3168/jds.2013-6679.

Sumner, C. L., M. A. G. von Keyserlingk, and D. M. Weary. 2018. How benchmarking motivates farmers to improve dairy calf management. J. Dairy Sci. 101:3323-3333. https://doi.org/10.3168/jds $.2017-13596$

Wagenaar, J. P. T. M., and J. Langhout. 2007. Practical implications of increasing "natural living" through suckling systems in organic dairy calf rearing. NJAS Wagening. J. Life Sci. 54:375-386. https: //doi.org/10.1016/S1573-5214(07)80010-8.

Weary, D. M., and B. Chua. 2000. Effects of early separation on the dairy cow and calf: 1 . Separation at $6 \mathrm{~h}, 1$ day and 4 days after birth. Appl. Anim. Behav. Sci. 69:177-188. https://doi.org/10 .1016/S0168-1591(00)00128-3.

\section{ORCIDS}

Rita Couto Serrenho (® https://orcid.org/0000-0002-7956-7039 Todd F. Duffield @ https://orcid.org/0000-0001-6035-4669 